\title{
A Mega Urban Project and Two Competing Accumulation Strategies: Negotiating Discourses of the Songdo International City Development
}

\author{
Jung Won SONN (University College London)^ \\ HaeRan SHIN (Seoul National University) \\ Se Hoon Park (Koran Research Institute for Human Settlement)
}

\begin{abstract}
${ }^{*}$ This research was partly funded by the Korean Research Institute for Human Settlement. A much earlier version of this paper appeared in the Institute's research report series, Shin, Sonn and Park (2010).

$\wedge$ During this research, Jung Won SONN had financial support from the Ministry of Education of the Republic of Korea and the National Research Foundation of Korea. Grant code NRF2015 S1A3A2047036.

${ }^{* *}$ Corresponding author
\end{abstract}

\begin{abstract}
For the understanding of the accumulation strategy behind a mega urban development project, the distinction should be made between the two different strategies of capital accumulation, which we term (1) rent-extraction strategy (RES) and (2) socioeconomic transformation of space strategy (STSS). This distinction is important because each is preferred by actors at different scales, thereby creating conflicts between them. Local actors are likely to prefer RES because its benefits mainly fall in the local area. National actors often prefer STSS because it symbolises state-level commitment to a business-friendly economic environment. Negotiation between these two strategies constitutes a major part of the formation of accumulation strategy. We test this theoretical prediction against the case of Songdo International City in South Korea. We find that the history of the project is consistent with our theoretical prediction.
\end{abstract}

KEY WORDS: South Korea, Songdo International City, Free Economic Zone, Accumulation Strategy, Mega Urban Development

\section{Introduction}

One of the distinctive features of neoliberal urban development is the prominence and prevalence of mega urban development projects such as the central business districts of Birmingham, Pudong (Shanghai), West Kowloon (Hong Kong), the Inner Harbour of Baltimore, and the Barcelona Olympic Village (Flyvbjerg, Bruzelius and Rothengatter, 2003; Kong, 2007; Lejano and Kan, 2015; Olds, 2001; Sklair, 2000; Yeoh, 2005). Students of cities 
often cite these megaprojects as evidence that the city has become the main scale of capital accumulation (Swyngedouw, Moulaert and Rodriguez, 2002).

We critique the existing literature for missing the political dimension in the shaping of such accumulation strategy behind these projects. Even if economic logic dictates the city as the 'right' scale for accumulation, accumulation strategy at the urban scale has to be imagined, uttered, and negotiated before it becomes the dominant vision. In understanding of that convoluted process, we claim, the distinction has to be made between the two different strategies of capital accumulation. We term these rent-extraction strategy (RES) and socioeconomic transformation of space strategy (STSS). Each is preferred by actors at different spatial scales, creating inter-scalar conflict.

To show the formation process of the accumulation strategy, we conducted an indepth case study of Songdo International City in South Korea. This project was chosen as our focus due to the complex changes it underwent, and because it is one of the most discussed large-scale urban development projects of recent years.

The rest of this paper consists of four parts. In the next section, we briefly review the existing literature on megaprojects, show that there is only an implicit distinction in existing literature between RES and STSS, and try to theorise these strategies in a more explicit manner. Section 3 explains the methodology of this paper, including a brief introduction to the Songdo case. Detailed historical analysis of Songdo's development, with a focus on the emergence of RES and STSS and the conflict between them, is offered in Section 4, which is followed by the conclusion.

\section{Megaprojects and Urbanization of Capital Accumulation in the Literature}

\section{Accumulation strategies through megaprojects}

Over the last two decades, planners, geographers, and sociologists have scrutinized diverse aspects of contemporary megaprojects. According to Orueta and Fainstein (2009), contemporary megaprojects are 'generally developed within the context of public-private partnership, are frequently mixed-use, and cater to the needs of office-based businesses and tourism and leisure services' (p. 760). In terms of governance, contemporary megaprojects are characterised by a bypassing of the traditional planning process. In London's Canary Wharf development, for instance, a non-elected committee consisting of elite members of the business and finance community was given decision-making power (Savitch and Kantor, 2002). This 'innovative' planning process reduces opportunities for residents' participation. 
In many cases, even local governments, which are supposed to safeguard the site against external interests, are left powerless (Moulaert et al., 2007). When situated in existing urban sites, megaprojects almost always gentrify the area as well (Kuyucu and Unsal, 2010). As resistance to gentrification increases the overall cost of a megaproject (Alshuler and Luberoff, 2004), megaprojects are increasingly placed in locations where such resistance is less likely (i.e., peripheral sites, landfills, or abandoned industrial sites) (Salet, 2008).

In all of the studies cited above, even if their main foci lie elsewhere (e.g., design, governance, and gentrification), terms relating to capital accumulation such as 'entrepreneurial government', 'neoliberalism', 'urban competitiveness', and 'capital attraction' are frequently used. These terms show how the studies' authors think of capital accumulation as the fundamental driver behind megaprojects, even though their works do not focus on capital accumulation itself. This paper provides this focus and improve the theoretical understanding of capital accumulation strategy in megaprojects.

\section{Retheorising two accumulation strategies}

Many authors on megaprojects seems to understand there are two different elements of a megaproject, i.e., physical upgrading of space and capital attraction. For example, Tusan-Kok distinguishes between 'large-scale urban regeneration' and 'spatial restructuring that will attract private investment to improve the social conditions of a larger territory' (Tusan-Kok, 2010: 126). Similarly, Majoor distinguishes between 'the physical space for important tertiary economic activities' and 'symbolic roles as strategic city marketing icons' (Majoor, 2011: 143). However, these authors do not point out that these two elements of a megaproject often reflect two different strategies of capital accumulation. We propose terming each strategy as a rent extraction strategy (RES) and a socio-economic transformation of space strategy (STSS). We argue that the two elements and associated accumulation strategies are preferred by actors at different scales, thereby triggering inter-scalar conflicts that influence the overall accumulation strategy.

The first of the two strategies, RES, is the pursuit of rent increase through a megaproject. This aim is accomplished by removing 'unfit' land use (e.g., social housing, old factories, and industrial warehouses) and adding prestige to the development with landmark buildings designed by renowned architects. Higher rent has always been an important aim of development but the contemporary RES has two new elements. 
First is the wider spread of such practices. Smith (2002) and Swyngedouw, Moulaert, and Rodriguez (2002) ascribe the wider spread of megaprojects to economic globalization weakening governments' ability to control capital flow. The built environment is not movable, so built-environment projects become the locus of accumulation strategies for actors who are bound spatially (Knox, 1991). The other element is the use of spectacle. As exemplified by Dubai and Pudong, Shanghai, the landscape and architectural designs have become more and more eye-catching with their sizes, heights, luxurious materials, and unique designs. The reason is that it is essential for the developers to make their projects recognizable and memorable to both potential tenants and the wider public.

These two characteristics of contemporary RES mark more than superficial differences. The spread of similar projects worldwide creates a situation in which there is an oversupply of prospective global cities. In the Marxist tradition, where built environment is considered a means of production, the current status can be considered to be an overaccumulation of capital in financial and service-purposed developments. When there is overaccumulation in the built-environment sector in general, achieving a normal rate of profit is not enough for a development to move ahead. Rather, the developer needs to aim at achieving excess profit. However, because there is insufficient general demand for space, tenants must be poached from other places (and the number of potential individual or corporate tenants is limited) leading to competition between first-rate developments.

The productivity of a built environment is sometimes determined by how well that environment facilitates production. However, a bigger part of productivity comes from the agglomeration economy the built environment hosts. Co-location of a certain number of key players is the critical factor, but few of those players will commit themselves without assurances that others would commit as well. When an agglomeration economy does not yet exist, the developer must sell a vision of an agglomeration economy, for which the developer employs various cultural tactics . Those tactics encompasses everything imaginable, from a landmark building designed by a top architect, to luxurious housing and living amenities like art galleries, to offices in prestigious architectural spaces. Only by assuring the prospect of agglomeration economy can corporate tenants be attracted, thereby actually creating an agglomeration economy.

The second strategy involves the use of megaprojects as symbol and catalyst for socioeconomic transformation, a strategy we term STSS. In this strategy, the physical developments are not the ultimate goal but 'a mediated objective, a necessary precondition for economic regeneration' (Swyngedouw, Moulaert, and Rodriguez, 2002: 553). In this 
strategy, urban megaprojects involve not only large-scale financing and fashionable design but also changes to the way the projects are governed. As Tewdwr-Jones and Phelps (2000) found, national or regional government often intervenes to streamline investment and bypass conventional local planning processes (see also Tarazona, 2016). Megaprojects may also receive exemption from legal regulations such as environmental, land use, and labour regulations and reductions in tax, creating a space from which the national state gives up part of its sovereignty (Ong, 2000).

Because this involves the production side (as opposed to the consumption side) of the built environment, there is a similarity between Keynesian megaprojects and STSS. However, from a capital-accumulation point of view, the new megaprojects differ from the old in many ways. The Keynesian welfare state planned and commissioned megaprojects that had a public-good nature. Infrastructure such as freeways, bridges, and dams was built by the state to provide income to businesses and workers. These infrastructure projects created demand for other goods, thereby helping various other sectors in the economy (Lipietz, 1987). Major megaprojects were built mainly when the economy downturned in order to even out the business cycle. The infrastructure turned sites into more productive spaces, thereby improving the long-term productivity of the entire economy (Harvey, 2010).

Like Keynesian megaprojects, STSS targets economic improvement. But there are important differences. First, typical Keynesian projects were productive infrastructure projects such as roads and dams, while new megaprojects are usually prestigious mixed-use urban development. Second, Keynesian projects were financed by the state with the aims of creating jobs and increasing effective demand as well as improving the long-term productivity of the given area. Job creation is one of the ultimate goals of STSS as well, but it is not an immediate one. The immediate goal is to attract capital, and job creation would be a desirable result of that immediate goal. Finally, the industries served by Keynesian megaprojects were not clear because the functions of social infrastructure are productive fixed capital and public good for public consumption at the same time. Unlike Keynesian strategy, STSS is usually designed to appeal to high-end productive services such as finance, legal and accounting services and the headquarter functions of multinational firms.

It should be noted here that STSS and RES are conceptual distinctions. Such distinctions help us understand the formation process of the accumulation strategy by illuminating the inter-scalar conflict. That is because RES and STSS have an unequal effect on accumulation at two different scales. 
RES is more likely to be supported by the coalition of spatially fixed actors at the local level (Cox and Mair, 1988; Logan and Molotch, 1987) than by actors at the national level. Under RES, much of the benefit from the development stays within the development area. An increase in land rent takes place within that site and the surrounding area. In fact, there is some evidence that a newly developed area attracts people and capital from other parts of the region rather than from other regions or other countries (Smith, 1996). Thus, such developments are more likely to be supported by the local elites, especially the land-owning class. When land-related taxes and levies are collected by the local government, when land is owned by the local government, or land-owning class is influential in local politics, local government is likely to be supportive of the project, too. Here it should be noted that 'local actors' include not only the endogenous local actors but also external actors with a vested interest in that locality. If a real estate developer invests significant resources in one project and the project's success determines her future, that investor is a local actor, even if she is from outside the locality or even outside the country. Similarly, a national politician whose political career is determined mainly by the local constituency's interest would be part of the local coalition, even if she is acting at the national scale.

Unlike RES, STSS is related to the national growth strategy. Thus, national actors are the main driving force, often in alliance with international actors with a neoliberal ideology such as International Monetary Fund and multinational investors. Pertinent here are Ong's (2000) and Park's (2005) discussions of special zones where the nation state limits its own sovereignty in order to better integrate that zone into the global circuit of capital flow. These studies in Asia are consonant with British case studies by Tewdwr-Jones and Phelps (2000) who found that the national government frequently intervenes in flagship multinational corporation investment sites. Such intervention is justified by the assumption that the benefits of foreign capital attraction are not confined to the investment site alone. On a symbolic level, the business-friendly image of the nation will be enhanced, thereby luring investment, job creation, and subcontracting opportunities that may benefit the regional as opposed to the local economy. Whether these perceived benefits will be realized is questionable (Sonn and Lee, 2012) but the competitiveness discourse is so dominant that national actors tend to assume these benefits will accrue.

A megaproject always involves both STSS and RES elements. For example, Canary Wharf London was a successful STSS for the then British Prime Minister, Margaret Thatcher, in the sense that the intensive involvement of prominent bankers and the exclusion of the local planning authority signalled to both people in the UK and investors around the world 
that she was committed to creating a business-friendly environment. At the same time, the site was a low-rent area considering its proximity to the city, because the previous use, light manufacturing, was declining. High-end offices and residential units certainly increased the rent, so it was a successful example of RES too.

It is always possible that the difference in the scale of the strategy might result in inter-scalar conflicts between differing interests at the local level and the national level. However, the differences between the RES and STSS are seldom noted. This neglect seems odd given the emerging consensus in political studies of cities on the nature of the state and its accumulation strategy. An increasing number of political scientists and political geographers recognize that an accumulation strategy is hardly an outcome of natural consensus. Instead, different groups of actors prefer alternative accumulation strategies (Jessop, 1990; Brenner, 2004; Brenner and Theodore, 2002). Following this view, we emphasize that even though the city is the 'right' scale for accumulation in contemporary capitalism, not all actors recognize this. We can also see that the 'right' accumulation strategy from the standpoint of national capitalism does not necessarily equate with the interest of all actors. For these reasons, the state's accumulation strategy is always the result of conflict and negotiation, and an economic strategy will only be a temporary articulation of diverse interests. In this paper, we are interested in understanding the process of this articulation, particularly in conflicts between local and national actors.

\section{Research Strategy}

We see accumulation strategy as a discourse or a collection of discourses following the Lancaster School of cultural political economy and their allies (Fairclough et al., 2004; Jessop and Oosterlynck, 2008; Moulaert, Jessop and Mohamid, 2016). An accumulation strategy is the vision for a megaproject, appearing in its most formalized form in the state's official development plan. However, key actors' understandings of such policies, their unofficial plans and hidden agendas, and the voice of the various civic groups collectively contest and constitute that vision. In other words, an accumulation strategy around a megaproject is a bundle of discourses that are only roughly and temporarily coherent-looking. It is difficult to hold together all actors with divergent interests and their views, so for a megaproject to go ahead, an accumulation strategy is needed that holds key actors together. No strategy can perfectly serve all actors' interests. Therefore, the best possible strategy is the kind that reminds key actors of their temporarily convergent interests and that persuades 
those actors that, at least for a limited period of time, concurrence is in their best interest (Sum, 2005). For this reason, actors engaged in political struggle attempt to create a sufficiently compelling vision to achieve intellectual and moral leadership. In this context, we look at how competing discourses come into conflict and fuse together in support of a common, if temporary, accumulation strategy.

Like the Lancaster School, we look at discourse without falling into 'discourse determinism' (Fairclough et al., 2004; Jessop and Oosterlynck, 2008; Moulaert, Jessop and Mohamid, 2016). A compelling vision is a necessary but not sufficient condition for the success of an accumulation strategy, as 'the social forces forming discursive chains... coconstruct, select and privilege certain objects' (Moulaert et al., 2007: 198). This view on discourse is maintained throughout this paper.

The case study, is the Songdo International City project of Inchon, South Korea. Songdo International City is a development on $53.4 \mathrm{~km}^{2}$ of reclaimed land (roughly the size of Manhattan). The site is located along Inchon's waterfront, $65 \mathrm{~km}$ west of Seoul. Connected to Inchon International Airport by the 18-km-long Inchon Bridge, the development cost over US $\$ 40$ billion, and includes the Northeast Asia Trade Tower, the Songdo Convensia Convention Centre, the Songdo International School, a museum, a cultural centre, the Jack Nicklaus Golf Course, and the Central Park. By the planned completion date of 2020, the area is expected to have 252,000 residents, 4.6 million square meter of office space, and 9.2 million square meter of retail space ( Inchon Free Economic Zone Authority [IFEZA], www.ifez.go.kr).

Figure 1. The Location of Songdo and a View of Songdo International City and developmental plan for Incheon Free Economic Zone

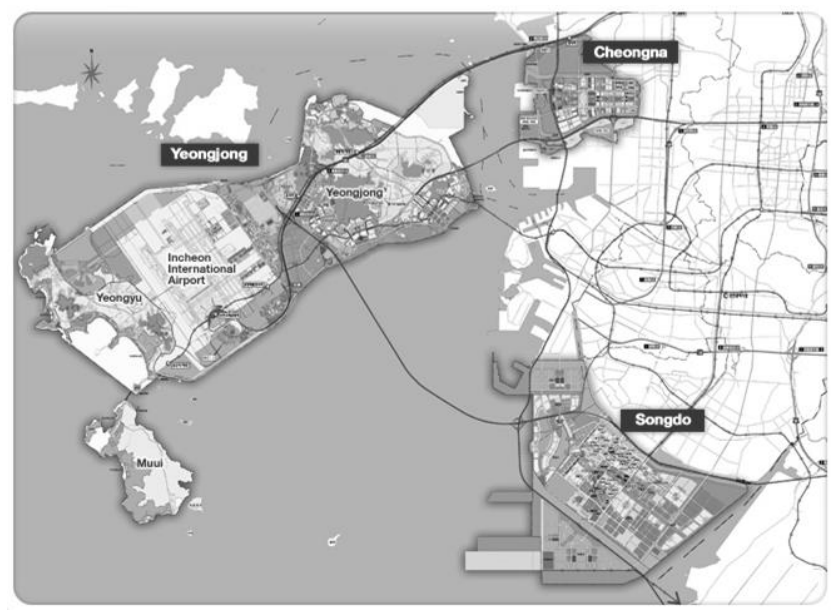

Source: www.Incheon Free Economic Zone.go.kr 
The discourses around this project are particularly complex, for two reasons. First, this project is one of the earliest to be initiated by a local government in South Korea. Yet the actions of the national state show that it still has strong control over the project. Second, almost three decades have elapsed since the initial articulation of this project. That is a long time in the Korean context, where economic growth and social changes have been extremely fast. This has resulted in the project being influenced by the emergence and/or intensification of external discourses such as globalization (paired with notions of national competitiveness) and growth control (paired with notions of interregional balance).

In addition to offering a good opportunity to study the discursive process of megaprojects, Songdo is an important case in and of itself. Recently, Songdo has attracted academic attention both as one of the largest megaprojects in recent years and as a smart city (Carvalho, 2015; Shwayri, 2013; Mullins and Shwayri, 2016; Van Winden et al. 2013). Many of the studies on Songdo rely heavily on the developer's, the governments', and other key stakeholders' publications and accept them at face value. In particular, the PR material of Cisco, which touts Songdo as the world's first smart city, seems to have strongly influenced academic research (e.g., Shelton, Zook and Wiig, 2016). In reality, when Cisco got involved in 2009, much of the land was already sold for end users, and IT infrastructure was contracted out to LG and KT. Therefore, a radical change in accumulation strategy was not feasible (Interview 13). By tracking the historical change in the accumulation strategy through indepth interviews, we can better understand the convoluted history of Songdo's development and provide insight into how the fundamentals of its development were determined before the advent of the smart-city concept. In-depth studies of Songdo do exist, but they mainly look at the speculative nature of development (Kim, 2014; Kim, 2010; Shin, 2016) or governance (Shin, Park and Sonn, 2015) and pay less attention to the overall accumulation strategy.

The empirical analysis in this paper is based on archival analysis and in-depth interviews. We collected archival material such as master plans, policy reports, newspaper articles, and meeting minutes to investigate the evolution of discourses. We also conducted in-depth interviews with members of elite groups involved in the project. These interviews focused on how the actors responded to others' views as well as how they produced certain discourses themselves. Archival searches and eleven interviews were conducted between December 2009 and December 2010, supplemented by two interviews conducted in 2016.

The thirteen interviewees included five from the Inchon government, one from the central government, three from governmental think tanks, one from civil society, one from 
the media, one from the developer, and one from a contractor. Each interview lasted approximately one-and-a-half hours. Internet searches identified media interviews by participants which were also collated and analysed. The selection of participants was based on snowballing method. If someone was mentioned as a key player in an interview, we asked the interviewee and other people to contact him or her. Interview questions included who initiated the project, what discourses and narratives they produced, what roles they played, and how they led discursive conflicts.

\section{Negotiating Two Accumulation Strategies in Songdo International City}

\section{Initial dominance of STSS and emergence of RES at the local level}

The entrepreneurial idea of a megaproject in the Inchon area was created in the late 1980s, a few years after the city gained independence from Gyongi Province, by a few bureaucrats and local leaders who felt the need for more aggressive growth policies. They specifically wanted to break free of the national government's growth control, which seemed to them, to be the main cause of economic stagnation in the city (Park, YS, 2008: 20-24). The main element of the plan was a large-scale reclamation and building of a high-quality business district, called East Asian Business Hub. The proposal was shared among only a handful of bureaucrats who organised the Inchon Public Development Centre within the Inchon government. These bureaucrats persuaded the mayor of Inchon to pursue this project.

Table 1. Timeline

\begin{tabular}{|c|c|c|}
\hline President & Year & Key Events \\
\hline \multirow[t]{4}{*}{ Chon Doo Hwan } & 1985 & $\begin{array}{l}\text { Local bureaucrats conceive of the Northeast Asian Business Hub for Songdo } \\
\text { and persuade the mayor of Inchon to pursue the project. }\end{array}$ \\
\hline & \multirow[t]{3}{*}{1987} & The Business Hub plan is reported to the president, with no effect. \\
\hline & & $\begin{array}{l}\text { Presidential candidate Roh Tae Woo's election pledge includes two } \\
\text { important built-environment projects that would influence the Songdo } \\
\text { project: 1) construction plans for two million houses and 2) a plan for the } \\
\text { Inchon International Airport. }\end{array}$ \\
\hline & & $\begin{array}{l}\text { Local bureaucrats change the title of the Songdo development to 'Songdo } \\
\text { New Town' to emphasise the housing element of the project. }\end{array}$ \\
\hline Roh Tae Woo & 1992 & The Inchon government completes the Songdo district development plan. \\
\hline \multirow[t]{2}{*}{ Kim Young Sam } & 1996 & The Media Valley Project is rejected by the Inchon Local Assembly. \\
\hline & 1997 & The East Asian economic crisis hits South Korea. \\
\hline \multirow[t]{3}{*}{ Kim Dae Joon } & \multirow[t]{2}{*}{2001} & The Inchon International Airport is completed. \\
\hline & & $\begin{array}{l}\text { The Inchon government exchanges a MOU with the Gale Company for the } \\
\text { latter's investment. }\end{array}$ \\
\hline & 2002 & $\begin{array}{l}\text { President Kim Dae Joong announces his support for the Songdo project as a } \\
\text { Free Economic Zone and promises the provision of the physical }\end{array}$ \\
\hline
\end{tabular}




\begin{tabular}{|c|c|c|}
\hline & & infrastructure. \\
\hline & & $\begin{array}{l}\text { The media starts to criticize the Inchon government for increasing the } \\
\text { housing element of the Songdo project. }\end{array}$ \\
\hline & & $\begin{array}{l}\text { The new administration announces its vision for a Northeast Asian Economic } \\
\text { Hub Nation. Under this vision, the administration supports the idea of a Free } \\
\text { Economic Zone in Songdo. }\end{array}$ \\
\hline \multirow[t]{2}{*}{ Roh Moo Hyun } & 2004 & $\begin{array}{l}\text { Songdo and two districts near Songdo are designated 'Inchon Free Economic } \\
\text { Zones', along with five other areas across the country. }\end{array}$ \\
\hline & 2005 & $\begin{array}{l}\text { The Songdo International Business District master plan is approved by the } \\
\text { central government. }\end{array}$ \\
\hline \multirow{4}{*}{$\begin{array}{l}\text { Lee Myung } \\
\text { Bak } \\
(2008-2013)\end{array}$} & 2009 & The first phase of development is completed. \\
\hline & 2010 & An MOU is signed with Cisco. \\
\hline & 2011 & State University of New York's Songdo campus opens. \\
\hline & 2012 & Inchon Ubiquitous City Corporation is founded. \\
\hline $\begin{array}{l}\text { Park Geun } \\
\text { Hye } \\
(2013-2017)\end{array}$ & 2015 & Daewoo International, a trading company moves in. \\
\hline
\end{tabular}

At this stage, the STSS elements were dominant. Local bureaucrats wanted to take advantage of the city's location in the Capital Region. They proposed hosting industries that required good access to Seoul, such as finance, tourism, and logistics. With this plan, the local government persistently lobbied President Chun Doo Hwan (1980-1988) and members of the National Assembly, arguing that the East Asian Business Hub would strengthen both Inchon's and South Korea's position in the global competition among cities and nations. The proposal was, however, quickly rejected by the Ministry of Construction, which stuck to the traditional discourses of interregional balance and growth control and would not permit major developments that would increase the population of the Capital Region. (Sonn, 2008) The national government did not have plans for the site.

However, when presidential candidate Roh Tae Woo pledged to build two million new homes in response to the nationwide housing crisis during the late 1980s, the local government saw an opportunity. After Roh's election in 1988, the Inchon government changed the name of the project to 'Songdo New Town' to signal to him that Songdo was a residential development that could contribute to the president's two-million-new-homes plan. This change, which we think of as an introduction of RES, persuaded several key bureaucrats in the national government to informally give the project a green light (Interviewees 5 and 7 , both employees of Inchon FEZ Authority).

For the key local bureaucrats, the title change did not mean a complete transformation from STSS to RES. Rather, they thought of it as lip service, with the highlighting of, or at 
most a nominal increase in, housing development that was already part of the Hub plan. To their surprise, the title change caused an unexpected discursive shift toward RES. It provided the silent majority of local actors an opportunity to challenge the more determined, better organised, hitherto more vocal minority in charge of the project. The majority of local actors thought a business hub development never been tested before and so was too risky. For them, housing development had been proven effective many times elsewhere within the Capital Region. With the nationwide housing crisis at that time, housing development certainly made better sense. The local government could easily sell the land to residential developers, leading to an apparent win-win situation of provision of a good new residential area as well as money to invest in other parts of the city. However, the advocates of a business hub strategy did not give in. Therefore, tension arose between the two groups as well as between the discourses of RES and STSS. The conflict became conspicuous around the 'Media Valley Project' proposal that was a part of the international business hub plan. Several members of the local assembly tried to stop the project on the grounds of a technicality. However, their real objection, all of our interviewees agree, was a preference on housing development. By the mid-1990s, it had become evident that there were two different visions of the project, or what we term RES and STSS.

\section{Sudden emergence of STSS at the national level and gradual takeover of RES at the local} level

As a researcher in a think tank of the national government (interviewee 11) said in our interview, the Songdo development 'would have been much more difficult if the Asian financial crisis had not happened'. The crisis was an opportunity for local actors to add national importance to the development project. That success, however, also meant that the national state became the development's dominant actor. This change is related to the emergence of the free economic zone (FEZ) as a policy tool.

FEZs have existed in South Korea since the 1970s. While FEZs meant exportprocessing zones before the 1997 financial crisis, after the crisis, they became a symbol of deregulation. The deregulation discourse had been around since the 1970s as a criticism of the authoritarian developmental state by liberals and big businesses (Sonn and Lee, 2015). However, the International Monetary Fund's diagnosis of the Korean economy further enhanced the legitimacy of deregulation, which is now seen as a way to enhance national competitiveness. Within the realm of urban and regional policy, the discussion on deregulation mainly revolved around growth control measures for the Capital Region. The proponents of 
deregulation argued that the Capital Region was the only region in Korea capable of competing against the world's other major city regions, so growth control for the sake of interregional balance only hurt national competitiveness. Local governments in the Capital Region, knowing they had allies at the national level, dared to attack the national government's growth regulation policies, a development that would have been unimaginable under non-crisis circumstances.

The Inchon government had to take advantage of this situation and gain the national government's final approval for the project. The Inchon government brought in Gale Company, an American property investor and developer, which agreed to participate on two conditions: 1) the city would be designated as a FEZ and 2) the government would provide its infrastructure (Park, YS, 2008; Lee, SC, 2005). In a meeting with President Kim Dae Jung in 2001, the mayor demonstrated that international business centre construction was going well in terms of hosting FDI. He emphasized that once a FEZ was designated, Gale would bring up to US \$6 billion in investment. The president promised strong support from the national government, because the idea of FEZs and Gale's investment fit perfectly with his strategy, which was the liberalisation of the economy (Inchon Ilbo [Inchon Daily Newspaper], 30 November 2001). ${ }^{1}$ President Kim Dae Jung announced in his New Year's speech on 14 January 2002, that the government would prepare a 'Strategy for a Business Hub of Northeast Asia.' The construction of mega-infrastructure was emphasized, and Inchon International Airport was the first on the list (Hankook Kyeongje Shinmun [Korea Economic Daily], 15 January 2002), exactly as Inchon had hoped. The official designation of a FEZ meant that the STSS of the Songdo project was fully fledged, with deregulation considered a necessary measure to attract FDI. Songdo thus became a space where the national state's sovereignty was limited and plugged into the global circuit of capital. Based on the Special Act on the Designation and Management of FEZs, the three separate pieces of reclaimed land in Inchon, including Songdo, were designated 'Inchon FEZ'. Along with Inchon, Busan and Gwangyang were also approved as FEZs due to the consideration of interregional balance.

Around the same time, tensions were rising between the national and local scales, and between STSS and RES. A local politician, ever mindful of the next election, would naturally

\footnotetext{
${ }^{1}$ However, it was later found that Gale was not the kind of global actor that the national competitiveness and FEZ discourses depicted. An ideal global actor would bring foreign money, do business in FEZs, and create jobs for Koreans. This small US-based developer was not capable of bringing in foreign money to start with. POSCO E\&C, a subsidiary of the Korean steel giant POSCO, assured with its asset for loans from domestic banks as the main contractor. Gale itself seemed to acknowledge POSCO to be the main driving force by advertising the project overseas with POSCO's name rather than its own; this was confirmed by our interview with interviewee 12.
} 
prefer a project favoured by his/her local constituency, hence Inchon Mayor Choi Giseun Choi (1995-2002) leaned toward RES. RES could be focused on various types of real estate, but in the South Korean context, particularly in the Capital Region, residential development was a surer way to realise capital accumulation. The mayor's view evidently influenced the project's shift further toward housing. A former employee of the FEZ authority, in an interview with us, claimed that the project had become 'just another housing development' because local actors did not have a 'global mindset'.

In this process, POSCO E\&C, the contractor and the developer's major shareholder, acted as a local actor. This is related to the unique structure of the building industry in South Korea. In South Korea, there is no major developer per se who would oversee a major development like Songdo. Rather, a temporary entity is created to act as a developer, and that entity is usually controlled by a major construction company whose main interest lies in building contracts rather than the long-term management of the site (Kim and Choi, 2015). As such, POSCO E\&C would have assumed full control of the New Songdo International City Development LLC (NSIC) if both POSCO E\&C and the Inchon Government needed Gale to package Songdo as an international project. Eventually POSCO E\&C and Gale each held $50 \%$ of the voting power in NSIC. However, POSCO E\&C's influence over NSIC was actually bigger than $50 \%$ because POSCO E\&C's assurance being crucial in financing the project and the company's connections with the Inchon local government, which used its planning authority to influence the project. As the contractor, POSCO E\&C's interest lies in maximizing the building contract and minimising the development period. As such, POSCO E\&C did not oppose the local government's shift toward residential development, with company documents on this project noting simply that "POSCO E\&C can have opportunities for U.S. \$100 million worth of contracts per year for the next ten years.” (POSCO E\&C, 2014)

The national government, according to interviewees 9 and 10 (employees of Inchon FEZ Authority), noticed Songdo's shift towards RES. Agencies in the national government, including the Office of the Prime Minister and the Board of Audit and Inspection, started strong criticism against the shift, which was supported by the national media. It was an explicit conflict between STSS and RES, which will be explained further in the next section.

\section{Local RES and national STSS}

Critical discourses were generated at the national scale by the national government and national media. The main criticism was that the Inchon government had made the FEZ 
into just another opportunity for property speculation and that attracting international businesses had been unsuccessful (Inchon Media Club, 2010). Interviewee 11, who works for a central government think tank, reflect the national government officials' views on Inchon's turn to RES., 'Local bureaucrats are corrupt. They are bribed to represent local builders' interest in this nationally important project'.

In the period in which this paper was written (2016), Songdo has been more successful in receiving FDI than have other places in South Korea. That does not mean, however, that Songdo recovered the RES elements it had been losing. As the Ministry of Trade, Industry, and Energy (2014) acknowledged, foreign investment in South Korea had been mainly for the domestic market rather than for the international market, so Songdo has been taking FDI from other South Korean cities rather than attracting those that could go to other countries. The biggest MNC that Songdo is hosting is the headquarters of Daewoo International, a trading company worth around US $\$ 2.5$ billion. That company is, however, a subsidiary of POSCO, meaning the developer itself ended up using the space. For these reasons, the criticism of Songdo's turning toward RES remains valid.

The local interviewees accept Songdo's turning toward RES, but they blamed the national state for this. They argue that national regulation was the reason the area's potential was not realised (also seen in Asia Kyung-je [The Asia Business Daily], 10 February 2010). They claimed that they had to increase housing development only because unnecessary regulations were making foreign investment nearly impossible. However, several local interviewees did agree, housing development was a safer strategy for development than the original business hub was.

Discursive conflicts occurred, not only around the general direction of the development but also around specific regulations. Long and tedious renegotiations resulted in compromises. For instance, a new Korean university is still forbidden, but a new campus of an existing Korean university is allowed. International primary and secondary schools, which previously could not admit more Koreans than 40 percent of their student bodies, were now allowed to do so. On other occasions the national government did not compromise. The Mayor's intention to use profits from the Songdo project to provide infrastructure for the regeneration of the city's old centre was prevented by the national government's Board of Audit and Inspection (Interviewee 4, a civil society activist).

The gradual dominance of STSS at the national level undermined the other less prominent FEZs that were either established alongside Inchon IFEZ or later based on regional balance discourse. To have a full-fledged STSS in Songdo, the national government needed 
to be more committed to Inchon FEZ, but the existence of the other five FEZs was an obstacle. Criticism of the influence of the interregional balance discourse on FEZs was rampant during the Roh administration that particularly emphasised interregional balance. Various experts and the media proposed that poorly performing FEZs should lose their FEZ status. The Roh administration did not accept that proposal, but the next, Lee administration did in 2010 (Korea Herald, 28 December 2010). In 2014, the national government reduced the sizes of the six FEZs by 22 per cent. The Inchon FEZ lost some land as well but those involved in Songdo welcomed this change. That was because the land that was lost was the peripheral parts for which an official development plan did not exist. Meanwhile, weakening of the other FEZs meant more support from the national government for Inchon FEZ, according to a former employee of Gale.

\section{Conclusion}

During the long development process, from the initial idea by a small number of local bureaucrats to today, various discourses have been formed to shape the Songdo project. At the local level, the main conflict was between the business hub strategy and the residential development strategy. What happened at the local level is consistent with our theoretical prediction. At the local level, STSS and RES coexisted and RES gradually took over. The fact that RES started as a response to the housing crisis discourse at the national level but eventually took over the project shows the strategy's power at the local level. While the benefits of STSS are unclear and unproven, those of RES were clear to major local actors. As such, RES was regarded as a safer strategy. That appreciation did not emerge solely because the development discourse was initiated by those with a grand vision of STSS. When the opportunity was given by the national level's housing crisis discourse, the silent majority started to raise their voices and eventually took over the project. Even after the East Asian economic crisis, when the national government placed the FEZ in the national discourse of economic recovery and created a favourable environment for STSS, local actors retained and even increased RES elements in Songdo and the other parts of the Inchon FEZ.

What happened at the national level coincides with our theoretical prediction. In the theoretical discussion, we argued that national actors are less likely to employ RES because the strategy's benefits are mainly confined to the local level, while the negative effects may reach other regions of the country. 
At the national level, the interregional balance discourse, the housing shortage discourse, and the national competitiveness discourse collided with one another in and around the Songdo project. While these three discourses competed at the national scale, the real accumulation strategy was that of STSS. The interregional balance discourse that prevailed at least until the 1997 economic crisis was a response to the discontent expressed by people outside Greater Seoul toward Greater Seoul's much faster development in terms of population, income level, cultural amenities, education, and so on since the 1960s. As such, that discourse might be considered a collection of local accumulation strategies. It might also be regarded as the legitimisation discourse at the national level in response to local dissatisfaction, but not as a national accumulation strategy. Housing development discourse at the national level was not mainly for capital accumulation either. The discourse was initiated by the president himself in the context of the presidential election, in which he had to respond to the housing crisis in the Greater Seoul region. As such, the main political function was a response to the housing crisis. Ruling out these two discourses, we can therefore argue that at the national level, there was no clear vision for capital accumulation in regards to Songdo until the 1997 East Asian economic crisis. The FEZ emerged as a part of the national competitiveness discourse during and after the crisis. Because the FEZ involved deregulation in terms of labour, environment, and currency, it amounted to the national state limiting its own sovereignty, which is typical of STSS.

This tendency shows that the agreed-upon urban development megaproject does not necessarily require a consensus among all actors involved. This is especially true between the national actors and the local actors, who are likely to have diverging visions that are only temporarily made compatible. The different visions can result in open conflict over or quiet subversion of the nature of the project. Without understanding this inter-scalar conflict or the possibility of such conflict, an important basis for understanding of the urban megaproject dynamics will be missed. Such an oversight exists in the current literature.

We tend to believe that our discussion of RES and STSS is not context-specific, although this generalisation requires evidence from other empirical settings. Regardless of the geographical location, the accumulation strategy of a contemporary mega project is a mixture of these two strategies. The spatial reach of the benefits of RES and STSS is dependent upon the nature of the strategies and is not necessarily determined by the local context. However, exactly how these two strategies are formed, how they collide and what the outcome will look like are certainly specific to the context. In Songdo's case, the dissolution of the 
developmental state, empowerment of the local government through local elections and the East Asian economic crisis of the late 1990s affected the process.

\section{References}

Altshuler, A. and David, L. (2004) Mega-Projects: The Changing Politics of Urban Public Investment, Brookings Institution Press.

Brenner, N. (2004) New State Spaces: Urban Governance and the Rescaling of Statehood, Oxford, Oxford University Press.

Brenner, N. and Theodore, N. (2002) 'Cities and the geographies of actually existing neoliberalism', Antipode, 34, 349-79.

Carvalho, L. (2015) 'Smart cities from scratch? A socio-technical perspective', Cambridge Journal of Regions, Economy and Society, 8(1), 43-60.

Cox, K.R. and Mair, A. (1988) 'Locality and community in the politics of local economic development', Annals of the Association of American Geographers, 78(2), 307-25.

Fairclough, N., Jessop, B. and Sayer, A. (2004) 'Critical realism and semiosis', in J. Joseph and J. Roberts (eds), Realism, Discourse and Deconstruction, London, Routledge, 2342.

Flyvbjerg, B., Bruzelius, N. and Rothengatter, W. (2003) Megaprojects and Risk: An Anatomy of Ambition, Cambridge, Cambridge University Press.

Harvey, D. (2010) Social Justice and the City, University of Georgia Press.

Inchon Media Club. (2010) A Report on Inchon Citizens Forum, 16 March, Inchon, Inchon Media Club

Jessop, B. and Oosterlynck, S. (2008) 'Cultural political economy: on making the cultural turn without falling into soft economic sociology', Geoforum, (39), 1155-69

Jessop, B. (1990) State Theory: Putting the Capitalist State in Its Place, Cambridge, Polity.

Kim, C. (2010) 'Place promotion and symbolic characterization of New Songdo City, South Korea', Cities, 27(1), 13-9.

Kim, J.I. (2014) 'Making cities global: the new city development of Songdo, Yujiapu and Lingang', Planning Perspectives, 29(3), 329-56.

Kim, Y., and Choi, M.J. (2015) 'Why have big construction companies replaced real estate developers in Korea?' International Journal of Urban Sciences 19(2), 206-223. 
Knox, P. (1991) 'The restless urban landscape: economic and sociocultural change and the transformation of metropolitan Washington, DC', Annals of the Association of American Geographers, 81, 181-209.

Kong, L. (2007) 'Cultural icons and urban development in Asia: economic imperative, national identity and global city status', Political Geography, 26, 383-404.

Kuyucu, T. and Ünsal, Ö. (2010). ' Urban transformation' as state-led property transfer: an analysis of two cases of urban renewal in Istanbul', Urban Studies, 47(7), 1479-99.

Lejano, R. P. and Wing-Shan, K. (2015) 'Seeing urban regeneration through an institutional lens: toward a new contextualism', International Journal of Urban Sciences, 19(3), 257-68.

Lee, S.C. (2005) 'The development of Free Economic Zone project in Korea: the case of Inchon Free Economic Zone', DongHyangGwaJeonMang, 65, 48-64.

Lipietz, A. (1987) Mirages and Miracles, London, Verso.

Logan, J. and Molotch, H. (1987) Urban Fortunes: The Political Economy of Place, Berkeley, University of California Press.

Majoor, S. (2011) 'Framing large-scale projects', Journal of Planning Education and Research, 31, 143-56.

Ministry of Trade, Industry and Energy. (2014) 'Policy measures for promotion of foreign investment, the first button for economic reform' (Press Release on 9 January), Ministry of Trade, Industry and Energy.

Moulaert, F., Martinelli, F., Gonzalez, S. and Swyngedouw, E. (2007) 'Introduction: social innovation and governance in European cities', European Urban and Regional Studies, 14(3), 195-209.

Moulaert, F., Jessop, B. and Mehmood, A. (2016) 'Agency, structure, institutions, discourse (ASID) in urban and regional development', International Journal of Urban Sciences, 20(2), 167-87.

Mullins, P. D. and Shwayri, S.T. (2016) 'Green cities and "IT839”: a new paradigm for economic growth in South Korea', Journal of Urban Technology, 23(2), 47-64.

Olds, K. (2001) Globalization and Urban Change: Capital, Culture and Pacific Rim Megaprojects, Oxford, Oxford University Press.

Ong, A. (2000). 'Graduated sovereignty in South-East Asia', Theory, culture \& society, 17(4), $55-75$.

Orueta, F. and Fainstein, S. (2008) 'The new mega-projects: genesis and impacts', International Journal of Urban and Regional Research, 32(4), 759-67. 
Park, B.G. (2005) 'Spatially selective liberalization and graduated sovereignty: politics of neo-liberalism and "special economic zones" in South Korea', Political Geography, 24(7), 850-73.

Park, Y.S. (2008) A man who changed the map of Korea, Seoul, Hangook Kyeongje Shinmun. POSCO E\&C (2014) POSCO Full History available at http://history20.poscoenc.com/?p=1381 (Access date: 26 February 2017)

Salet, W. (2008) 'Rethinking urban projects: experiences in Europe', Urban Studies, 45(11), 2343-63.

Savitch, H.V. and Kantor, P. (2002) Cities in the International Marketplace, Princeton, Princeton University Press.

Shelton, T., Zook, M. and Wiig, A. (2015) 'The 'actually existing smart city', Cambridge Journal of Regions, Economy and Society, 8(1), 13-25

Shin, H. R., Park, S. and Sonn, J.W. (2015) 'Rescaling governance? A network approach to rescaling of a mega project', Environment and Planning C, 33(6), 1618-38.

Shin, H. (2016) 'Envisioned by the state: entrepreneurial urbanism and the making of Songdo city, South Korea', in A. Datta and A. Shaban (eds), Mega-Urbanization in the Global South: Fast Cities and New Urban Utopias of the Postcolonial State, London, Routledge.

Shwayri, S. (2013) 'A model Korean ubiquitous eco-city? The politics of making Songdo', Journal of Urban Technology, 20(1), 39-55.

Sklair, L. (2000) The Transnational Capitalist Class, Oxford, Blackwell.

Smith, N. (1996) The New Urban Frontier: Gentrification and the Revanchist City, London, Routledge.

Smith, N. (2002) 'New globalism, new urbanism: gentrification as global urban strategy', Antipode, 34(3), 427-51.

Sonn, J.W. and Lee, D. (2015) 'Heterogeneity as the source of the state's resilience', International Journal of Urban Sciences, 19(3), 364-78.

Sonn, J.W. (2010) 'Contesting state rescaling: an analysis of the South Korean state's discursive strategy against devolution', Antipode, 42(5), 1200-24.

Sonn, J.W. and Lee, D. (2012) 'Revisiting the branch plant syndrome', International Journal of Urban Sciences, 16(3), 243-59.

Sum, N.L. (2005) 'Towards a Cultural Political Economy: Discourses, Material Power and (counter-) Hegemony' (Working Paper Series), DEMOLOGOS. 
Swyngedouw, E., Moulaert, F. and Rodriguez, A. (2002) 'Neoliberal urbanization in Europe', Antipode, 34(3), 547-82.

Tarazona, V.A. (2017) 'Mega-project meltdown: post-politics, neoliberal urban regeneration and Valencia's fiscal crisis', Urban Studies, 54(1), 68-84.

Tasan-Kok, T. (2010) 'Entrepreneurial governance: challenges of large-scale property-led urban regeneration projects', Tijdschrift voor Economische en Sociale Geografie, 101(2), 126-49.

Tewdwr-Jones, M. and Phelps, N.A. (2000). 'Leveling the uneven playing field', Regional Studies, 34, 429-40.

Van Winden, W., De Carvalho, L., van Tuijl, E., van Haaren, J. and Van den Berg, L. (2013) Creating Knowledge Locations in Cities: Innovation and Integration Challenges, London, Routledge.

Yeoh, B. (2005) 'The global cultural city? Spatial imagineering and politics in the (multi) cultural marketplaces of South-east Asia', Urban Studies, 42(5-6), 945-58. 